\title{
The New "Good Samaritans": Digital Helpers During Pandemic Times in Canada1
}

\author{
Fernando Mata \\ fmata@uottawa.ca \\ Jennifer Dumoulin \\ Department of Communication, University of Ottawa \\ jdumo098@uottawa.ca
}

School of Sociological and Anthropological Studies, University of Ottawa

March 28, 2021

\begin{abstract}
During times of crises such as the present COVID-19 pandemic in Canada, digital helpers emerge as key agents of the promotion of digital literacy in society. Using data from the CPSS-5 national survey, the authors looked at the digital help provided by individuals to various demographic cohorts during the pandemic period in Canada. This survey comprised 3,961 adult respondents aged 15 years old who were interviewed in September, 2020. Digital helpers assisted fellow Canadians in through navigating digital technologies such as videoconferencing, online voice chats, online shopping sites or educational resources. Digital helpers comprised $48 \%$ of the total adult population where the most typical form was the assistance of adult respondents aged 18 to 64 years old. Assistance to specific demographic cohorts such as children, teens and seniors varied according to the sociodemographic profiles of helpers. Multivariate analysis of seven typical types of digital help suggests that the likelihood of digital help increased with a younger age of the helper, the presence of a child living at home, university education, urban residence status and/or living in large households. Overall, digital help outcomes appeared to be linked to the life course position of the individual and the types of family or non family networks situated around the helper. The role of young married women living with children and other individuals as the new "Good Samaritans" of digital help is relevant in this regard.
\end{abstract}

\subsection{Introduction}

The sanitary measures imposed during the global COVID-19 pandemic has forced citizens around the globe to practice social/physical distancing and to retrench themselves at home. The way to communicate with others is now done through the use of social media which involves some

\footnotetext{
1 Paper to be presented at the 2021 CSA Meetings, Edmonton-Alberta. The authors would like to thank the Ontario Data Documentation, Extraction Service and Infrastructure (ODESI-Scholars Portal Statistics) as well as Statistics Canada for making available the data and valuable support and guidance.
} 
knowledge of communication technologies. Members of society who are not well-versed in these technologies, are suddenly tasked to learn how to do so by themselves, which often led to frustration and even despair.

Communication technologies are critical sources of information and interchange during crises situations such as the current COVID-19 emergency occurring in Canada (Drouin, 2020; Weiderhold, 2020). New technologies offer both younger and older audiences alternative communication opportunities from those offered by traditional media such as newspapers, radio and T.V. (Valkenburg and Piotrowski, 2017). Video-based platforms such as TikTok have become popular during the confinement period because they enable users to quickly upload, convert, store and play back video content on the Internet. Zoom, Skype, Google Hangouts, and other real-time videoconferencing platforms have replaced in-person meetings in professional and personal settings. Online discussion forums and online blogs are also popular online discussion sites allowing people to hold conversations in the form of posted messages.

The COVID-19 crisis, however, has exacerbated the magnitude of the digital divide which already separates Canadians in terms of access and use of communication technologies. This digital divide has been connected to demographic and residential factors such as geographic location (i.e. rural vs. urban), education and particularly age (Schmidt, 2012; Haight, Quan-Haase, \& Corbett, 2014; Mata and Dumoulin, 2020). Digitally challenged population segments have limited access to services and platforms stemming from the absence of crucial digital infrastructure and/or unfamiliarity with recent communication technologies. A good illustration of this case is the use of the Internet as the main source of information about COVID-19 developments in Canada. A previous Canadian national survey (CPSS-4), similar in nature of the one used for the present analysis, found that use of the Internet for this purpose was in the order of $85 \%$ in rural areas compared to $91 \%$ in urban ones. Use of this technology monotonically decreases with age brackets particularly for male and female rural residents in Canada (see chart 1). A steep decline in Internet use for males is noticeable earlier at ages 35-44 years old while for females it is observable at later age cohorts.

In times of crises such as national disasters, political upheaval and/or epidemics, volunteers and local actors often play a crucial role in emergency response and recovery ${ }^{2}$. Crisis "crowd-sourcing", which facilities the sharing of information between government officials, non-governmental organizations and everyday citizens, has been used to coordinate emergency response efforts and provide up-to-date, on-the-ground information for those in need such as during natural disasters

\footnotetext{
2 See the 2015 World Disasters Report issued by the International Federation of the Red Cross and the Red Crescent Societies noted the "the critical yet often undervalued role of local actors" in crisis situations (p.8).
} 
(see King, 2018). In addition, various studies have shown that where technological disparities exist between different groups, digital helpers may come to the aid of digitally disadvantaged groups (see Starbird and Palen, 2011).

Digital helpers are individuals who donate their time and resources to promote digital literacy and digital skills among their fellow citizens. Although digital skills have, in the past, been categorized as "basic" and "advanced" (see van Deursen \& van Dijk, 2010), more recent literature has emphasized their sequential and simultaneous nature in the pursuit of a specific digital goal. From this perspective, a digital helper "break[s] down an end goal into constituent skills, or steps, of varying levels of complexity, such as managing multiple password-protected accounts, or writing a CV in a word processor before uploading it to a website" (Allmann \& Blank, 2021). These steps often require both 'basic' and 'advanced' skills to be deployed simultaneously. Digital helpers represent a form of informal volunteering, which is broadly defined as any assistance given directly-that is, not through a formal organization - to individuals such as a relative, neighbour, acquaintance or friend (Lee and Brudney, 2012). In Canada, informal volunteering has been found as important to Canadians as formal volunteering (Statistics Canada, 2009). In a number of social groups and disadvantaged communities, informal volunteering is the dominant type of helping behaviour compared to that of formal volunteering (Carson, 1999; Wilson, 2000).

Chart 1: Percentage of the Canadian Adult Population Regularly Using the Internet as an Information source for COVID-19 Developments in Canada

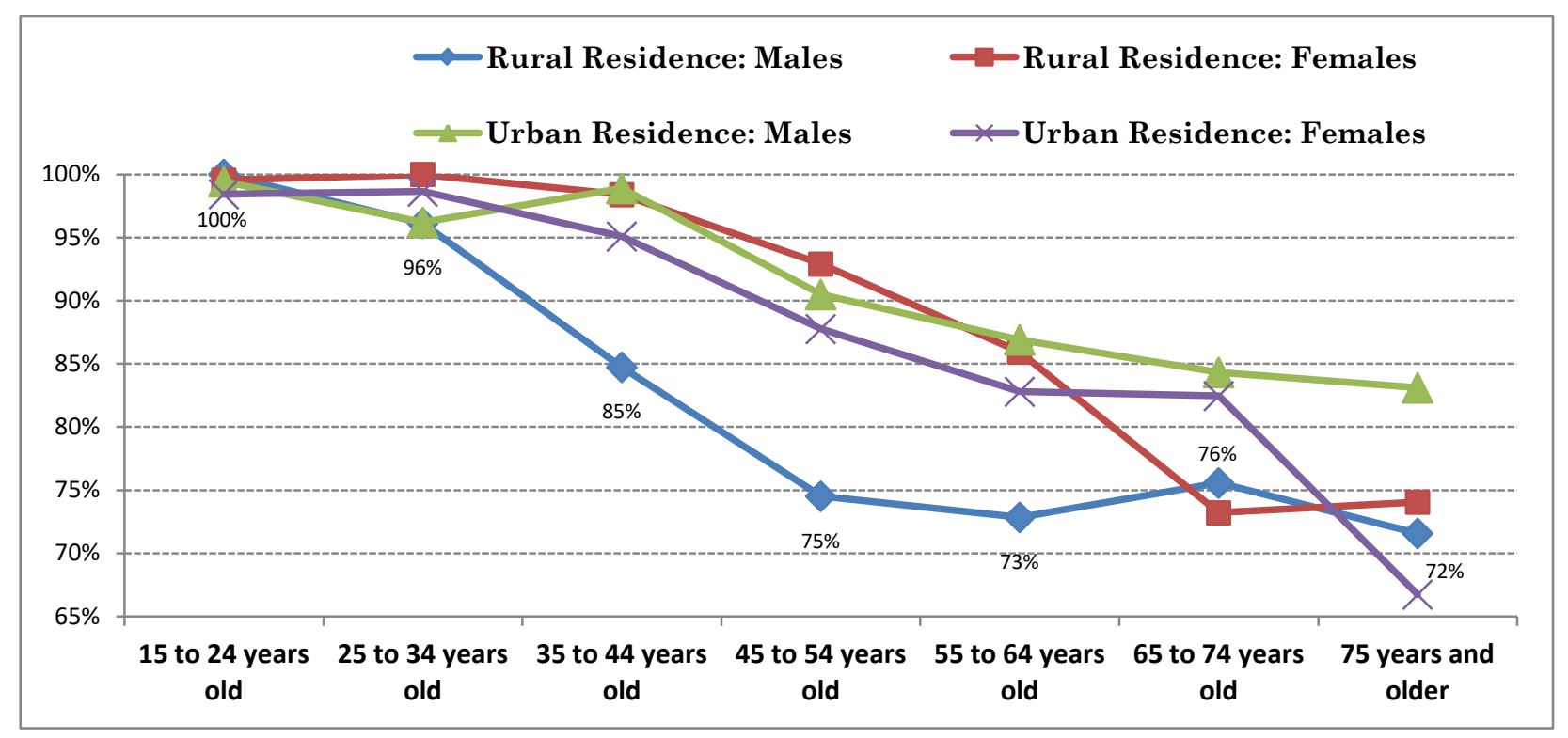

Source: CPSS-Series4 Survey, Statistics Canada, 2020 
It is expected that during the COVID-19 pandemic in Canada, digital volunteers share their Internet skills and social media knowledge with others in the home, as well as in schools, workplaces, hospitals, places of worship and other private and public spaces. Several research questions regarding digital help become pertinent at this historical juncture. For example, what is the level of involvement of Canadians in the promotion of digital literacy during the pandemic period? What demographic cohorts are the typical targets of digital helpers? What are the socio-demographic profiles of helpers and non-helpers? What are the best predictors of digital help in Canada? Statistics Canada's CPSS (Canadian Perspectives Survey Series) survey data offers unique opportunities for studying the digital help phenomenon in Canada. The CPSS surveys, which started in March 2020, are short online surveys directed at adult Canadians. Using data from the fifth CPSS survey (CPSS-5), the present paper focuses its attention on the involvement of digital helpers in assisting various demographic cohorts and on the socio-demographic profiles of these individuals. Descriptive statistics regarding digital help are followed by a multivariate analysis of the types of digital help using logistic regression analysis.

\subsection{Data Sources and Measures}

The CPSS-5 survey was conducted from September 14 to September 20, 2020. It comprised a national representative sample of 3,961 adult respondents aged 15 years old and over. The probability panel of this survey was created by randomly selecting a subset of the Labour Force Survey (LFS) respondents. Aside from digital help, the CPSS-5 survey collected information on digital helpers within the broader variety of topics including cyber security practices, incidents and consumer spending during the pandemic. ${ }^{3}$

The digital help behaviour of respondents during the pandemic period was captured by 5 binary type of questions (CS_35A to CS_35E): "Since the beginning of the COVID-19 pandemic, which of the following groups have you helped to navigate digital technologies such as videoconferencing, online voice chats, online shopping sites or educational resources?" $(0=$ No, $1=$ Yes) The following demographic cohorts targeted for digital help were chosen by survey respondents: CS_35A: Children cohorts, 10 years old or younger; CS_35B: Teenager cohorts, 11 to 18 years old. CS_35C: Adult cohorts: 19 years old to 64 years old, CS_35D: Senior cohorts: 65 years or older, CS_35E: None: Did not help others. Based on the responses to these questions, seven types of digital help and one non-digital help type were identified. Types of digital help were matched to selected socio-demographic characteristics of digital helpers

\footnotetext{
3 More information about this survey is available at https://www150.statcan.gc.ca/n1/daily-quotidien/201014/dq201014aeng.htm.
} 
including their age, gender, marital status, education level, urban residence status, presence of children 18 years old or younger, immigrant status and household size where the respondent lived.

\subsection{Digital Help Findings}

\subsection{Almost half of Canadian adults are engaged in digital help during the Pandemic}

According to the CPSS-5, 48\% (representing 14.7 million individuals) of the Canadian adult population engaged in digital help behaviour and helped fellow citizens navigate digital technologies since the beginning of the pandemic in March 2020 (see chart 2). Demographic cohorts helped included a majority who helped adults only (15\% of the total population), followed by those who helped seniors only (9\%) and those who helped older cohorts (children and teens, 17\%). "Super" digital helpers, those who assisted all four demographic cohorts, represented about $5 \%$ of the total population (about 1.4 million Canadians).

Chart 2: Digital Help and its Types (\%), Canadian Adults 2020

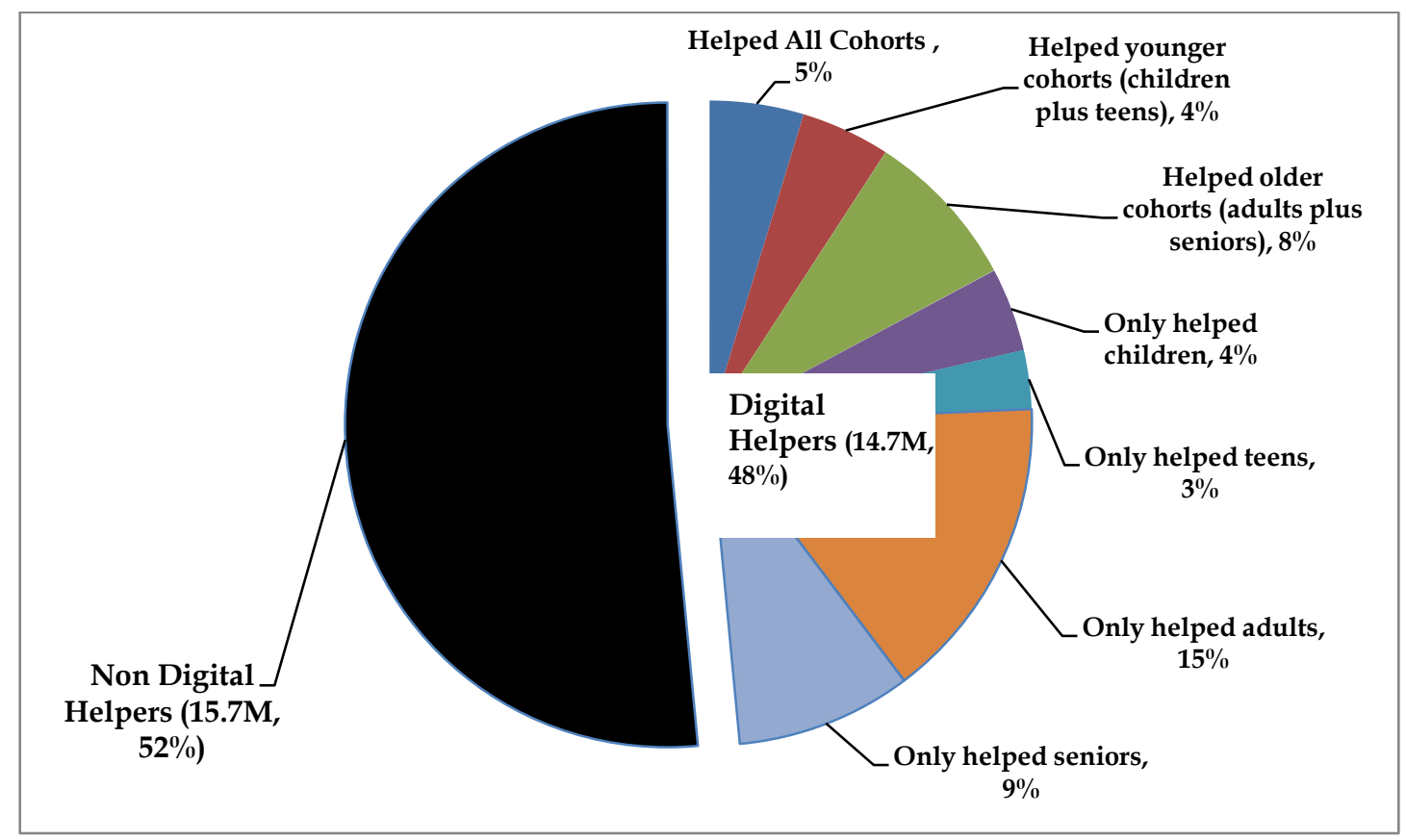

Source: CPSS-Series5 Survey, Statistics Canada, 2020 


\subsection{Younger Canadians, university-educated and urban residents are over- represented among digital helpers}

The socio-demographic profiles of helpers are presented in table 2. These profiles reveal sharp contrasts between those engaged in digital help and those who do not. Four out of ten digital helpers were 35 years old or younger ${ }^{4}, 32 \%$ were single, $45 \%$ had attained university education and about $88 \%$ lived in urban areas. Non-digital helpers were a relatively older group (i.e. about a third were aged 65 years old and over), only $26 \%$ had attained university education and $20 \%$ were rural residents. Also noticeable in the table is that $44 \%$ of digital helpers had children under 18 living with them while this percentage among digital helpers was lower at only 19\%. Overall, individuals living in a larger households were over-represented in the digital help group compared to the nondigital help one (39\% to $25 \%$ ). No major differences in terms of gender and immigrant status composition were found in the data.

Table1: Socio-Demographic Profiles of Digital and Non-Digital Helpers, Canada 2020

\begin{tabular}{|l|r|r|r|}
\hline $\begin{array}{l}\text { Socio-Demographic } \\
\text { Characteristics }\end{array}$ & $\begin{array}{r}\text { Digital } \\
\text { Helpers }\end{array}$ & $\begin{array}{r}\text { Non-Digital } \\
\text { Helpers }\end{array}$ & $\begin{array}{r}\text { Total } \\
\text { Population }\end{array}$ \\
\hline N (thousands) & $14,716.9$ & $15,628.4$ & $30,345.3$ \\
\% & $48 \%$ & $52 \%$ & $100 \%$ \\
Age & & & \\
Under 35 years old & $41 \%$ & $23 \%$ & $32 \%$ \\
35-64 years old & $49 \%$ & $45 \%$ & $33 \%$ \\
65+ years old & $11 \%$ & $32 \%$ & $30 \%$ \\
Gender & & & $50 \%$ \\
Males & $51 \%$ & $49 \%$ & $50 \%$ \\
Females & $49 \%$ & $51 \%$ & $28 \%$ \\
Marital Status & & & $60 \%$ \\
Single & $32 \%$ & $24 \%$ & $12 \%$ \\
Married & $60 \%$ & $61 \%$ & $38 \%$ \\
Widowed/Separated/Divorced & $8 \%$ & $15 \%$ & $31 \%$ \\
High School or less & & & $30 \%$ \\
Non University & $26 \%$ & $41 \%$ & $16 \%$ \\
University & $28 \%$ & $34 \%$ & $84 \%$ \\
Place of Residence & $45 \%$ & $26 \%$ & \\
Rural & & & $69 \%$ \\
Urban & $12 \%$ & $20 \%$ & $31 \%$ \\
Presence of Children Under 18 & $88 \%$ & $80 \%$ & $77 \%$ \\
No & & & $23 \%$ \\
Yes & $56 \%$ & $81 \%$ & $68 \%$ \\
Immigrant Status & $44 \%$ & $19 \%$ & $32 \%$ \\
Canadian Born & & & \\
Foreign Born & & $78 \%$ & \\
Number of Household Members & $75 \%$ & $22 \%$ & \\
3 or less & $25 \%$ & $75 \%$ & \\
4 or more & $61 \%$ & $25 \%$ & \\
& $39 \%$ & & \\
Total Population & & $100 \%$ & \\
\hline
\end{tabular}

Source: CPSS-Series5 Survey, Statistics Canada, 2020

\footnotetext{
${ }^{4}$ About $95 \%$ of those CPSS- 5 respondents aged 15-24 were single while $42 \%$ of those aged $24-35$ were also single. In contrast, about $66 \%$ of those aged 65 years old and over were married and $26 \%$ were either widowed, separated or divorced.
} 


\subsection{Digital help directed at adult Canadians (18-64 years old) as the most typical pattern of digital help}

Charts 3 and 4 display the percentages corresponding to male and female helpers of different age groups within the context of other types of digital help. For male helpers, the adult targeted rate reaches its peak at ages 25-34 and 55-64 of the helper hovering around the 20\% mark. Among female helpers, this activity reaches its peak at younger ages 15-24 and 25-34 of the helper suggesting female helpers start providing assistance at earlier ages compared to men. The rate of help directed to adult Canadians declines with the age of the helper. As helpers get older, they start to provide more help to fellow seniors. One major difference between male and female helpers is that, compared to males, the female cohort aged 35-44 significantly increases its assistance to younger cohorts (children and teens) reaching a younger cohort targeted rate of about $19 \%$.

Chart 3: Demographic Groups targeted by Digital Helpers (\%) by Age and Gender of Helper, Male Adults Canada 2020

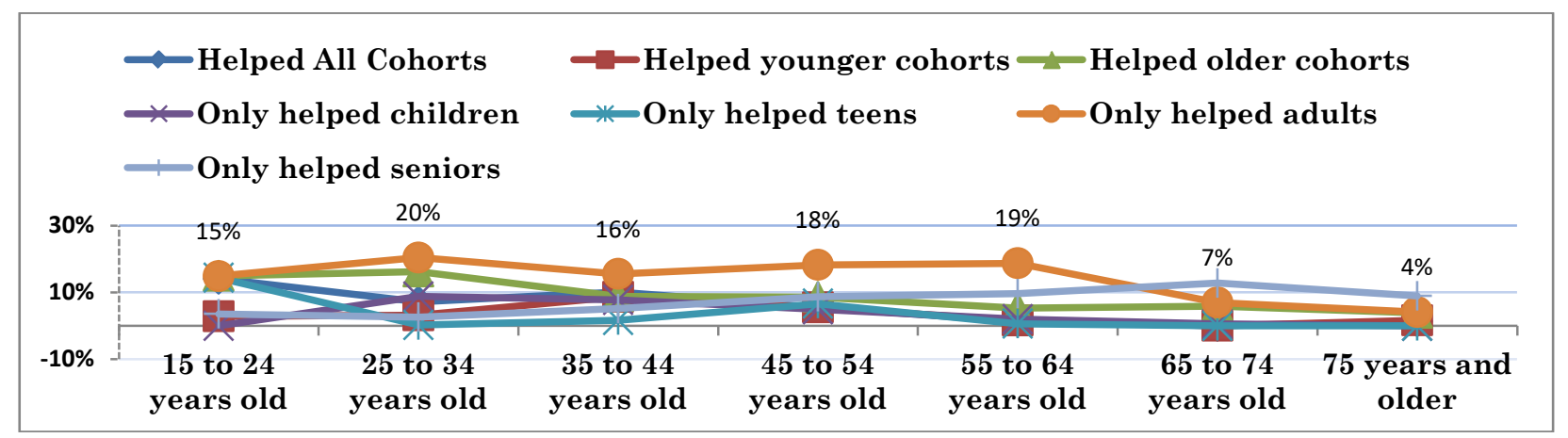

Source: CPSS-Series5 Survey, Statistics Canada, 2020

Chart 4: Demographic Groups targeted by Digital Helpers (\%) by Age and Gender of Helper, Female Adults Canada 2020

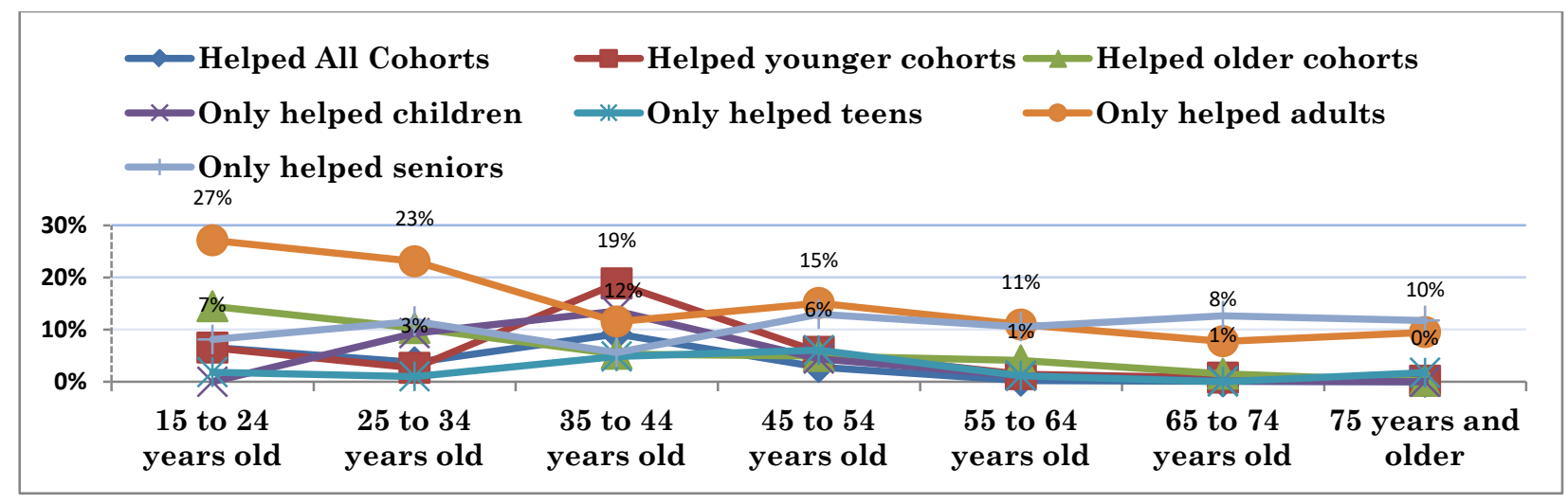

Source: CPSS-Series5 Survey, Statistics Canada, 2020 
Table 2: Types of Digital Help (\% with respect to total population) by Selected Socio-demographic characteristics of helpers, Canadian Adults 2020*

\begin{tabular}{|c|c|c|c|c|c|c|c|c|}
\hline $\begin{array}{l}\text { Socio-Demographic } \\
\text { Characteristics }\end{array}$ & $\begin{array}{l}\text { Helped } \\
\text { All } \\
\text { Cohorts } \\
(1)\end{array}$ & $\begin{array}{l}\text { Helped } \\
\text { younger } \\
\text { cohorts } \\
\text { (2) }\end{array}$ & $\begin{array}{c}\text { Helped } \\
\text { older } \\
\text { cohorts } \\
(3)\end{array}$ & $\begin{array}{c}\text { Only } \\
\text { helped } \\
\text { children } \\
\text { (4) }\end{array}$ & $\begin{array}{c}\text { Only } \\
\text { helped } \\
\text { teens } \\
(5)\end{array}$ & $\begin{array}{c}\text { Only } \\
\text { helped } \\
\text { adults } \\
(5)\end{array}$ & $\begin{array}{c}\text { Only } \\
\text { helped } \\
\text { seniors } \\
\text { (7) }\end{array}$ & $\begin{array}{c}\text { All } \\
\text { Digital } \\
\text { Help } \\
\text { Average }\end{array}$ \\
\hline \multicolumn{9}{|l|}{ Age groups } \\
\hline 15 to 24 years old & $5 \%$ & $4 \%$ & $8 \%$ & $4 \%$ & $3 \%$ & $15 \%$ & $9 \%$ & $7 \%$ \\
\hline 25 to 34 years old & $6 \%$ & $3 \%$ & $13 \%$ & $9 \%$ & $1 \%$ & $22 \%$ & $7 \%$ & $9 \%$ \\
\hline 35 to 44 years old & $10 \%$ & $14 \%$ & $7 \%$ & $11 \%$ & $3 \%$ & $15 \%$ & $5 \%$ & $9 \%$ \\
\hline 45 to 54 years old & $4 \%$ & $6 \%$ & $7 \%$ & $5 \%$ & $6 \%$ & $17 \%$ & $11 \%$ & $8 \%$ \\
\hline 55 to 64 years old & $1 \%$ & $2 \%$ & $5 \%$ & $2 \%$ & $1 \%$ & $15 \%$ & $10 \%$ & $5 \%$ \\
\hline 65 to 74 years old & $0 \%$ & $0 \%$ & $4 \%$ & $0 \%$ & $0 \%$ & $7 \%$ & $13 \%$ & $3 \%$ \\
\hline 75 years and older & $1 \%$ & $1 \%$ & $2 \%$ & $0 \%$ & $1 \%$ & $7 \%$ & $11 \%$ & $3 \%$ \\
\hline \multicolumn{9}{|l|}{ Gender } \\
\hline Male & $6 \%$ & $4 \%$ & $8 \%$ & $4 \%$ & $4 \%$ & $15 \%$ & $7 \%$ & $7 \%$ \\
\hline Female & $3 \%$ & $9 \%$ & $6 \%$ & $4 \%$ & $2 \%$ & $15 \%$ & $10 \%$ & $6 \%$ \\
\hline \multicolumn{9}{|l|}{ Marital Status } \\
\hline Single & $6 \%$ & $4 \%$ & $15 \%$ & $1 \%$ & $4 \%$ & $18 \%$ & $8 \%$ & $6 \%$ \\
\hline Married/Common Law & $3 \%$ & $5 \%$ & $6 \%$ & $5 \%$ & $2 \%$ & $19 \%$ & $8 \%$ & $3 \%$ \\
\hline Widowed/Separated/Divorce & $5 \%$ & $2 \%$ & $2 \%$ & $4 \%$ & $1 \%$ & $12 \%$ & $7 \%$ & $5 \%$ \\
\hline \multicolumn{9}{|l|}{ Education Level } \\
\hline Non University & $3 \%$ & $4 \%$ & $8 \%$ & $4 \%$ & $2 \%$ & $14 \%$ & $9 \%$ & $6 \%$ \\
\hline University & $6 \%$ & $6 \%$ & $9 \%$ & $6 \%$ & $2 \%$ & $17 \%$ & $10 \%$ & $8 \%$ \\
\hline \multicolumn{9}{|l|}{ Place of residence } \\
\hline Rural & $5 \%$ & $3 \%$ & $7 \%$ & $3 \%$ & $2 \%$ & $10 \%$ & $6 \%$ & $5 \%$ \\
\hline Urban & $5 \%$ & $5 \%$ & $8 \%$ & $4 \%$ & $3 \%$ & $16 \%$ & $9 \%$ & $7 \%$ \\
\hline \multicolumn{9}{|l|}{$\begin{array}{l}\text { Presence of Children Under } \\
18\end{array}$} \\
\hline No & $2 \%$ & $1 \%$ & $10 \%$ & $0 \%$ & $0 \%$ & $15 \%$ & $11 \%$ & $6 \%$ \\
\hline Yes & $10 \%$ & $12 \%$ & $5 \%$ & $13 \%$ & $9 \%$ & $15 \%$ & $5 \%$ & $10 \%$ \\
\hline \multicolumn{9}{|l|}{ Immigrant Status } \\
\hline Born in Canada & $5 \%$ & $4 \%$ & $8 \%$ & $3 \%$ & $3 \%$ & $14 \%$ & $9 \%$ & $7 \%$ \\
\hline Foreign-Born & $3 \%$ & $5 \%$ & $8 \%$ & $7 \%$ & $3 \%$ & $19 \%$ & $7 \%$ & $7 \%$ \\
\hline \multicolumn{9}{|l|}{ Household Size } \\
\hline 3 members or less & $4 \%$ & $4 \%$ & $7 \%$ & $5 \%$ & $3 \%$ & $14 \%$ & $9 \%$ & $7 \%$ \\
\hline 4 or more members & $9 \%$ & $5 \%$ & $12 \%$ & $1 \%$ & $3 \%$ & $27 \%$ & $9 \%$ & $9 \%$ \\
\hline Total & $5 \%$ & $4 \%$ & $8 \%$ & $4 \%$ & $3 \%$ & $15 \%$ & $9 \%$ & $7 \%$ \\
\hline
\end{tabular}

Source: CPSS-Series5 Survey, Statistics Canada, 2020

\subsection{The type of digital help varied according to the demographic profile of the helper}

Table 2 presents the percentage rates of types of digital provided by socio-demographic characteristics of respondents to the CPSS-5 survey. The table reveals that the likelihood of being a "super helper", that is providing assistance to all demographic cohorts, increases to $10 \%$ 
when the helper is aged 35-44 years old and either/or has children living at home. Assistance to younger cohorts (children plus teens) peaks to $14 \%$ when the helper is in a similar age bracket and also has a child living at home (12\%). Older cohort (adults plus seniors) digital assistance is the highest when the helper is aged 25-34 (13\%), is single (15\%) or lives in a larger household of 4 or more members (12\%). Specific digital assistance to children is the highest when the helper is aged 35-44 (11\%) and to teens when the helper is aged 45-54 years old (6\%). Assistance to adult cohorts, the dominant pattern of digital help, is particularly visible among those helpers living in larger households (27\%), who are foreign-born (19\%), university-educated $(17 \%)$ and living in urban areas (16\%). Finally, specific digital assistance to older Canadians is greater when the helper is also older, is female (10\%) and /or has no children under 18 living at home (11\%). Overall, findings from the CPSS-5 survey suggests that there is a close association between the life course stage of the helper and targeted demographic cohort chosen for assistance. This finding is consistent with recent research on the "grey divide" - the digital divide affecting older adults - which has demonstrated that there is variation in their levels of digital skills, literacy and technology use (see Quan-Hasse et al., 2018). It is therefore not surprising that older digital helpers, those between 65-74 and 75 or older, assisted only older cohorts (13\% and $11 \%$ respectively), as they may physically located in the same place.

\subsection{Multivariate Analysis: The presence of children in the household is the most consistent predictor across digital help types}

To identify the most consistent predictors of types of digital help, binary logistic regressions were carried out having different types of digital help as dependent variables and examined the net impacts that specific socio-demographic predictors have on them in the presence of other correlates $^{5}$. Conditional odds ratios (ORs) corresponding to the seven regressions are presented in table 3. With respect to "super helpers" who digitally assisted all demographic cohorts (type 1), the ORs for younger ages of helpers, the presence of children, university education, urban residence and living in larger households were found statistically significant predictors. With regards to older cohort assistance (type 3), assistance to adults (type 6) and assistance to seniors (type 7), the main socio-demographic predictors were of a similar nature to those found for the "super helper" group. However, when digital assistance to younger cohorts is examined (type 2), not all these former variables are found important in the prediction of this particular type of digital help. Here, for instance, female helpers were 1.49 times more likely than males to engage in this particular behaviour while those who lived with children were 1.15 times more

\footnotetext{
${ }^{5}$ Due to the high correlations of age groups with marital status (e.g. younger cohorts of helpers and single marital status), this latter variable was excluded from multivariate analysis.
} 
likely than those who did not to do the same. Other variables appeared to have minor effects.

The ORs found for children digital assistance (type 4) revealed that women, those who lived with children and notably the foreign-born were engaged in this type of digital help. Compared to the Canadian-born, immigrants were 1.40 times more likely to engage in digital assistance to children. Also, with respect to specific digital assistance directed to teens (type 5), the 45-54 cohort of helpers is a predictor worthy of notice jointly with being female and living with a child in the household. This latter predictor was found as the most consistent across all types of digital help examined.

Table 3: Logistic Regression Results: Odds Ratios of Selected Socio-Demographic Predictors of Types of Digital Help Provided, Canada 2020

\begin{tabular}{|c|c|c|c|c|c|c|c|}
\hline \multirow[b]{2}{*}{$\begin{array}{l}\text { Socio Demographic } \\
\text { Predictors }\end{array}$} & \multicolumn{7}{|c|}{$\begin{array}{l}\text { Digital Help Types (Binary } \\
\text { variables, } 0=\text { no, } 1=\text { yes) }\end{array}$} \\
\hline & $\begin{array}{c}\text { Type 1: } \\
\text { Helped } \\
\text { All } \\
\text { Cohorts }\end{array}$ & $\begin{array}{l}\text { Type2: } \\
\text { Helped } \\
\text { younger } \\
\text { cohorts } \\
\text { (children } \\
\text { and teens) }\end{array}$ & $\begin{array}{l}\text { Type 3: } \\
\text { Helped } \\
\text { older } \\
\text { cohorts } \\
\text { (adults } \\
\text { and } \\
\text { seniors) }\end{array}$ & $\begin{array}{c}\text { Type 4: } \\
\text { Only } \\
\text { helped } \\
\text { children }\end{array}$ & $\begin{array}{c}\text { Type 5: } \\
\text { Only } \\
\text { helped } \\
\text { teens }\end{array}$ & $\begin{array}{c}\text { Type 6: } \\
\text { Only } \\
\text { helped } \\
\text { adults }\end{array}$ & $\begin{array}{c}\text { Type 7: } \\
\text { Only } \\
\text { helped } \\
\text { seniors }\end{array}$ \\
\hline Age & & & & & & & \\
\hline 15 to 24 years old & $10.80^{* *}$ & $1.82 \mathrm{~ns}$ & $24.71^{* *}$ & $0.13 \mathrm{~ns}$ & $1.53 \mathrm{~ns}$ & $10.58^{* *}$ & $1.00 \mathrm{~ns}$ \\
\hline 25 to 34 years old & $8.37^{*}$ & $0.95 \mathrm{~ns}$ & $11.46^{* *}$ & $0.15 \mathrm{~ns}$ & $1.30 \mathrm{~ns}$ & $5.68^{* *}$ & $0.79 \mathrm{~ns}$ \\
\hline 35 to 44 years old & $11.97^{* *}$ & $2.38 \mathrm{~ns}$ & $10.86^{* *}$ & $0.09 \mathrm{~ns}$ & $2.09 \mathrm{~ns}$ & $4.81^{* *}$ & $0.44 \mathrm{~ns}$ \\
\hline 45 to 54 years old & $9.36^{*}$ & $2.42 \mathrm{~ns}$ & $7.61^{* *}$ & $0.17 \mathrm{~ns}$ & $4.69^{* *}$ & $4.54^{* *}$ & $0.98 \mathrm{~ns}$ \\
\hline 55 to 64 years old & $1.38 \mathrm{~ns}$ & $1.37 \mathrm{~ns}$ & $4.25^{* *}$ & $0.09 \mathrm{~ns}$ & $1.48 \mathrm{~ns}$ & $3.70^{* *}$ & $0.84 \mathrm{~ns}$ \\
\hline 65 to 74 years old & $0.32 \mathrm{~ns}$ & $0.43 \mathrm{~ns}$ & $2.88^{* *}$ & $0.11 \mathrm{~ns}$ & $0.33 \mathrm{~ns}$ & $1.50 \mathrm{~ns}$ & $0.76 \mathrm{~ns}$ \\
\hline $\mathrm{RC}=75+$ years old & & & & & & & \\
\hline Gender & & & & & & & \\
\hline Females & $.73 \mathrm{~ns}$ & $1.49 *$ & $.56 \mathrm{~ns}$ & $1.50 * *$ & $1.88^{* *}$ & $0.80^{* *}$ & $1.38^{* *}$ \\
\hline $\mathrm{RC}=$ Males & & & & & & & \\
\hline Presence of Children & & & & & & & \\
\hline With Children & $1.72^{* *}$ & $1.15^{* *}$ & $2.08^{* *}$ & $1.72^{* *}$ & $1.79 * *$ & $1.61^{* *}$ & $1.45^{* *}$ \\
\hline $\mathrm{RC}=$ No Children & & & & & & & \\
\hline Place of Residence & & & & & & & \\
\hline Urban & $2.22^{* * *}$ & $1.44 \mathrm{~ns}$ & $1.52^{* *}$ & $1.20 \mathrm{~ns}$ & $1.03 \mathrm{~ns}$ & $1.38^{* *}$ & $1.35^{*}$ \\
\hline $\mathrm{RC}=$ Rural & & & & & & & \\
\hline Education Level & & & & & & & \\
\hline University & $4.35^{* *}$ & $8.33 \mathrm{~ns}$ & $0.29 \mathrm{~ns}$ & $20.00 \mathrm{~ns}$ & 11.11ns & $1.43^{* *}$ & $1.63^{* *}$ \\
\hline $\begin{array}{l}\mathrm{RC}=\text { Non University } \\
\text { Immigrant Status }\end{array}$ & & & & & & & \\
\hline Foreign-born & $0.43 \mathrm{~ns}$ & $0.83 \mathrm{~ns}$ & $0.85 \mathrm{~ns}$ & $1.41^{* *}$ & $1.00 \mathrm{~ns}$ & $1.14 \mathrm{~ns}$ & $0.76^{* *}$ \\
\hline $\mathrm{RC}=$ Canadian Born & & & & & & & \\
\hline Household Size & & & & & & & \\
\hline $\begin{array}{l}4 \text { members or more } \\
R C=3 \text { members or less }\end{array}$ & $2.08^{* *}$ & $1.04 \mathrm{~ns}$ & $1.30^{* *}$ & $7.69 \mathrm{~ns}$ & $0.33 \mathrm{~ns}$ & $2.08^{* *}$ & $1.27^{* *}$ \\
\hline Likelihood Ratio Chi-Square & $261.4^{* *}$ & $267.00 * *$ & $130.8^{* *}$ & $345.1^{* *}$ & $153.2^{* *}$ & $158.3^{* *}$ & $52.9^{* *}$ \\
\hline
\end{tabular}

Source: CPSS-Series5 Survey, Statistics Canada, 2020

Symbols: $\mathrm{RC}=$ reference category, $\mathrm{ns}=$ non statistically significant coefficient, ${ }^{*}=$ statistically significant coefficient at the $\mathrm{p}=.05$ level, ${ }^{* *}=$ statistically significant coefficient at the $\mathrm{p}=.01$ level 


\subsection{Concluding Thoughts: Digital Help in Canada's Pandemic Times}

Digital literacy is formally defined as "the ability to use information and communication technologies to find, evaluate, create, and communicate information, requiring both cognitive and technical skills" (American Library Association, 2013). Like their biblical counterparts, this study has shown that some Canadians are now becoming the "Good Samaritans" of digital help (following Luke 10:33) by being charitable with their computer/internet skills and actively supporting other fellow citizens during the pandemic period.

Almost half (48\%) of Canadian adults engaged in digital help to others during pandemic times in Canada. There is clear over-representation of youth (under 35 years old) among digital helpers suggesting that these individuals are very involved in helping others to communicate and expand their communication technologies horizons. Although digital aid was directed mostly at adults 18-64 years old, there was some variation depending on the socio-demographic characteristics of helpers. Female helpers reached out to younger cohorts while senior helpers helped other fellow seniors. The presence of children living at home, university education, urban residence and living in large households were also found to be strong correlates of digital help behaviour. The multivariate analysis of the data revealed that the presence of children living with the helper was found to be the most consistent predictor of all types of digital help suggesting that, for many Canadians, the spectrum of help occurred within "bubbles" 6 (directed mostly at children) but also projected itself outside to other "bubbles" where digital assistance is required.

Under a life course perspective, digital help may be seen as a behavioural characteristic of "linked" lives, that is, of people who occupy mutually influential interlocking developmental trajectories that extend throughout their lives (Elder, Johnson, \& Crosnoe, 2003). The life stage of younger Canadian demographic cohorts often coincides with advancing post-secondary education, leaving the parental home, starting new families and the earliest years of careerbuilding. This particular demographic segment is uniquely positioned to provide digital help to people within their networks and have, perhaps, some degree of economic freedom to assist others more effectively. As Canadians age, their spectrum of digital help expands from the adult population to other demographic cohorts such as children, teens and older adults who may struggle with the constant advances of communication technologies. The role of young married

\footnotetext{
"A "bubble" is an unofficial term used in Canada to describe people with whom the individual feels comfortable spending time during the pandemic (e.g. the household). .
} 
women with children as digital helpers, in particular, is relevant in this regard. During the pandemic, they are actively sharing their technical abilities with their own children, other children, as well as elderly parents. Their digital help spectrum expands as they age and, thus, becomes more multi-setting and multi-generational.

Finally, another point raised by the study is that older Canadians and rural residents appear somewhat limited in terms of their digital literacy skills and capacity to provide digital help to others in pandemic times. The CPSS-5 survey did not provide specific information on the population segment being helped but it is likely that digital helpers of all types most likely were engaged in the assistance of the most digitally disadvantaged groups. There is, therefore, a strong need to create special strategies and programs of digital literacy to facilitate the work of the new "Good Samaritans" of digital help and effectively reach disadvantaged segments to include them in a rapidly evolving technological world. This is especially important in emergency and crisis situations, where information is diffused rapidly via social media and other emerging digital technologies and platforms.

\section{References:}

Allmann, Kira, and Grant Blank. (2021). Rethinking Digital Skills in the Era of Compulsory Computing: Methods, Measurement, Policy and Theory." Information, Communication \& Society, 1-16, DOI: 10.1080/1369118X.2021.1874475.

American Library Association (2013). ALA Task Force releases digital literacy recommendations, Digital Literacy Task Force (2013), Retrieved from http://www.ala.org/news/press-releases/2013/06/ala-task-forcereleasesdigital-literacy-recommendations.

Carson, E. D. (1999) "On Defining and Measuring Volunteering in the United States and Abroad.” Law and Contemporary Problems, 1999, 62(4), 67-71.

Drouin, M; McDaniel; B. Pater, J. and Toscos, T. (2020). How Parents and Their Children Used Social Media and Technology at the Beginning of the COVID-19 Pandemic and Associations with Anxiety, Cyberpsychology, Behaviour and Social Networking, Vol 23(11).

Elder, G. H., Johnson, M. K., \& Crosnoe, R. (2003). The emergence and development of life course theory. In J. T. Mortimer, \& M. J. Shanahan (Eds.), Handbook of the life course (pp. 3 - 19). New York: Kluwer Academic/Plenum.

Haight, M.; Quan-Haase, A., and Corbett, B.A. (2014). Revisiting the Digital Divide in Canada: The Impact of Demographic Factors on Access to the Internet, Level of Online Activity, and Social Networking Site Usage, Information, Communication \& Society, Vol 17(4), pp.503-519.

International Federation of Red Cross and Red Crescent Societies (2015). 2015 World Disasters Report: Focus On Local Actors, The Key To Effectiveness. Geneva, Switzerland: IFRC. Available at https://reliefweb.int/sites/reliefweb.int/files/resources/1293600-World-Disasters-Report-2015_en.pdf

King, L.J. (2018). Social Media Use During Natural Disasters: An Analysis of Social Media Usage During Hurricanes Harvey and Irma, Proceedings of the International Crisis and Risk Communication Conference (pp. 20-23), Orlando, FL, USA. Nicholson School of Communication, https://doi.org/10.30658/icrcc.2018.6. 
Lee, Y. and Brudney, I. (2012). Informal Volunteering; Implications for Volunteer Recruitment, Nonprofit Management \& Leadership, vol. 23(2), Winter 2012.

Mata, F. and Dumoulin, J. (2020). Social and Non Social Media Users During The COVID-19 Pandemic Confinement Period in Canada: The "Plugged-In", Unplugged and Other Population Segments, available at: https://osf.io/preprints/socarxiv/ax9vm/

Quan-Haase, A. et al. (2018). Dividing the Grey Divide: Deconstructing Myths About Older Adults' Online Activities, Skills, and Attitudes, The American Behavioral Scientist, 62(9): 1207-1228.

Schmidt, C.W. (2012). Trending now: Using Social Media to Predict and Track Disease Outbreaks. Environmental Health Perspectives, Vol. 120(1), A30+. https://link.gale.com/apps/doc/A278773889/AONE?u=otta77973\&sid=AONE\&xid=96d02f51

Starbird, K and Palen, L. (2011). "Voluntweeters": Self-Organizing by Digital Volunteers in Times of Crisis, Proceedings of the International Conference on Human Factors in Computing Systems, CHI 2011, Vancouver, BC, Canada, May 7-12, 2011.

Statistics Canada. (2009). Caring Canadians, Involved Canadians: Highlights from the 2007

Canada Survey of Giving, Volunteering, and Participating, Ottawa: Statistics Canada, Catalogue no. 71-542XPE, ISBN 978-1-100-11869-7.

Valkenburg, P.M and Piotrowski, J.T. (2017) Plugged In: How Media Attract and Affect Youth Yale University Press, New Haven.

van Deursen, A.J.A.M, \& van Dijk, J.A.G.M. (2010). Measuring Internet Skills. International Journal of HumanComputer Interaction, 26(10), 891-916.

Wiederhold, B.K.(2020) Using Social Media to Our Advantage: Alleviating Anxiety During a Pandemic. Cyberpsychology, Behavior, and Social Networking 2020, (23):197-198.

Wilson, J. (2000) “Volunteering.” Annual Review of Sociology, 2000, 26, 215-240. 